\title{
PENGARUH MOTIVASI KERJA DAN KEPEMIMPINAN TERHADAP KINERJA PEGAWAI PADA KANTOR KECAMATAN PUSAKAJAYA KABUPATEN SUBANG
}

Oleh : Harries Madiistriyatno, Witler Slamat Halomoan S, Toto Suharto Adiwijayaemail : harries.madi@gmail.com;Totosuharto1969@gmail.com

\section{ABSTRACT}

The success of an organization can not be separated from the quality leader, because a quality leader was able to utilize existing resources within the company, have the ability to direct the activities of subordinates that led, in anticipation of any changes that occur suddenly, it can correct any weaknesses No, could bring the organization to the agreed goals within a predetermined time.

Especially for government agencies, particularly in the health sector providing motivation to employees should be continued. This meant that attitude, loyalty and commitment to the Pusakajaya district office increases so that every job will be easier to be completed on time and on target

The problems in this study is whether the motivation and leadership significant effect on the performance of employees at Pusakajaya district office Subang? and whether the motivation and leadership partially significant effect on the performance of employees at Pusakajaya district office Subang? The sampling technique systematic method of proportionate stratified random sampling. Data analysis techniques multiple linear regression analysis

This research resulted in the conclusion that the motivation and leadership together a significant effect on the performance of employees at Pusakajaya district office Subang. These results can be seen from the F count of 30,650 with a significance level of 0.000 , which is smaller than á $0.000<0.050)$. The influence of work motivation and leadership to employees performance of 50.5\% while the remaining $49.5 \%$ is influenced by other variables outside of this study. Motivation, and leadership is partially significant effect on the performance of employees at Pusakajaya district office Subang. These results can be seen from the t work motivation of 6.272 with a significance level of 0.006 which is smaller than á $(0.000<0.050)$ and the $t$ variable leadership of 5.906 with a significance level of 0.000 , which is smaller than á $(0.000<0.050)$.

Keywords: Motivation, Leadership and Performance

\section{PENDAHULUAN}

\section{Latar Belakang Masalah}

Kemajuan perusahaan atau organisasi tentunya didukung oleh kinerja karyawan. Seseorang dapat dikatakan mempunyai kinerja yang baik, manakala mereka dapat melaksanakan pekerjaan dengan baik, artinya mencapai sasaran dengan atau menurut standar yang ditentukan dengan penilaian kinerja, dengan kata lain akan mendorong karyawan untuk bersaing memperoleh penghargaan, bonus atau dipromosikan untuk jabatan yang lebih baik.

Kinerja adalah tingkat keberhasilan seorang karyawan dalam melaksanakan atau menyelesaikan pekerjaan. Baik buruknya kinerja seorang karyawan dapat dipengaruhi oleh banyak faktor, beberapa di antaranya akan dibahas dalam penelitian ini seperti motivasi kerja, kepemimpinan. Karyawan agar mau bekerja pada umumnya harus mempunyai motivasi. Motivasi berarti suatu kondisi yang mendorong atau menjadi penyebab seseorang melakukan suatu perbuatan atau kegiatan, yang berlangsung secara sadar.

Faktor yang mempengaruhi kinerja adalah motivasi kerja selanjutnya menjelaskan bahwa motivasi mempunyai kekuatan kecenderungan seseorang atau individu untuk melibatkan diri dalam kegiatan yang mengarah kepada sasaran dalam pekerjaan sebagai kepuasan, tetapi lebih lanjut merupakan perasaan senang atau rela bekerja untuk mencapai tujuan pekerjaan. Jika pemberian motivasi dan pelaksanaan kepemimpinan tidak dijalankan dengan baik maka suatu organisasi akan sulit untuk

1* Dosen Program Pascasarjana Magister Manajemen Sekolah Tinggi Manajemen IMMI 
dapat tetap bertahan dan memenangkan persaingan dalam menghasilkan pelayanan yang memuaskan bagi masyarakat. Kemajemukan konsumen ini bagaikan pedang bermata dua dengan multiplier effect-nya. Jika layanan yang mereka rasakan positif, maka potensi untuk words of mouth tinggi, demikian juga sebaliknya.

Dan keberhasilan suatu organisasi juga tidak terlepas dari kualitas pemimpinnya, sebab pemimpin yang berkualitas itu mampu memanfaatkan sumber daya yang ada dalam suatu lembaga, memiliki kemampuan untuk mengarahkan kegiatan bawahan yang dipimpinnya, mengantisipasi segala perubahan yang terjadi secara tiba-tiba, dapat mengoreksi segala kelemahan-kelemahan yang ada, sanggup membawa organisasi kepada tujuan yang telah disepakati dalam jangka waktu yang telah ditetapkan.

Keberhasilan dan kegagalan suatu perusahaan atau organisasi ditentukan oleh kepemimpinan, bentuk kepemimpinan yang efektif akan berdampak pada kemajuan perusahaan atau organisasi dalam menghadapi tantangan dan perubahan yang terjadi. Seorang pemimpin yang baik adalah mampu memanfaatkan seluruh sumber daya manusia yang, sehingga kepemimpinan merupakan bagian penting dalam meningkatkan kinerja karyawan pada perusahaan.

\section{PERUMUSAN MASALAH}

1. Apakah ada pengaruh Motivasi Kerja secara parsial terhadap Kinerja Pegawai di Kantor Kecamatan Pusakajaya Kabupaten Subang?

2. Apakah ada pengaruh Kepemimpinan secara parsial terhadap Kinerja Pegawai di Kantor Kecamatan Pusakajaya Kabupaten Subang?

3. Apakah ada pengaruh Motivasi dan Kepemimpinan secara simultan terhadap Kinerja Pegawai di Kantor Kecamatan Pusakajaya Kabupaten Subang?

\section{LANDASAN TEORI \\ Tinjauan Pustaka \\ Teori Motivasi}

Istilah motivasi, dalam kehidupan sehari-hari memiliki pengertian yang beragam baik yang berhubungan dengan perilaku individu maupun perilaku organisasi. Namun, apapun pengertiannya motivasi merupakan unsur penting dalam diri manusia, yang berperan mewujudkan keberhasilan dalam usaha atau pekerjaan manusia. Dasar utama pelaksanaan motivasi oleh seorang pimpinan adalah pengetahuan dan perhatian terhadap perilaku manusia yang dipimpinnya sebagai suatu faktor penentu keberhasilan organisasi.

Motivasi dapat ditafsirkan dan diartikan berbeda oleh setiap orang sesuai tempat dan keadaan dari para masing-masing orang itu. Pandangan para penulis tentang motivasi sangat bervariasi menurut sudut pandang masing-masing. Menurut Hasibuan (2003) menyatakan bahwa, "Motivasi adalah pemberian daya penggerak, yang menciptakan kegairahan kerja seseorang, agar mereka mau bekerja sama, bekerja efektif dan terintegrasi dengan segala daya upayanya untuk mencapai kepuasan".

Menurut Nursalam (2008:67) Motivasi adalah :

karakteristik psikologis manusia yang memberi kontribusi pada tingkat komitmen seseorang. Hal ini termasuk faktor-faktor yang menyebabkan, menyalurkan, dan mempertahankan tingkah laku manusia dalam arah tekad tertentu .

Menurut Robbins \& Coulter, (2007:98) Motivasi adalah :

"Proses kesediaan melakukan usaha tingkat tinggi untuk mencapai sasaran organisasi yang dikondisikan oleh kemampuan usaha tersebut untuk memuaskan kebutuhan sejumlah individu. Meskipun secara umum motivasi merujuk ke upaya yang dilakukan guna mencapai setiap sasaran, disini kita merujuk ke sasaran organisasi karena fokus kita adalah perilaku yang berkaitan dengan kerja.

Menurut Suarli dan Bahtiar, (2010:89)

Oleh sebagian besar ahli, proses motivasi diarahkan untuk mencapai tujuan. Tujuan atau hasil yang dicari karyawan dipandang sebagai kekuatan yang bisa menarik orang. Memotivasi orang adalah proses manajemen untuk mempengaruhi tingkah laku manusia berdasarkan pengetahuan mengenai apa yang membuat orang tergerak.

Motivasi menurut Hasibuan (2001: 219) adalah pemberian daya penggerak yang menciptakan kegairahan kerja seseorang, agar mau bekerja sama, bekerja efektif dan terintegrasi dengan segala daya upayanya untuk mencapai kepuasan.

Pengertian motivasi menurut Handoko (1992: 9), yaitu suatu tenaga atau faktor yang terdapat di dalam diri manusia, yang menimbulkan, mengarahkan dan mengorganisasikan tingkah lakunya.

\section{Teori Kepemimpinan \\ Pengertian Kepemimpinan}

Kepemimpinan secara harfian berasal dari kata pimpin. Kata pimpin mengandung pengertian mengarahkan, membina atau mengatur, menuntun dan juga menunjukkan ataupun mempengaruhi. 
Pemimpin mempunyai tanggung jawab baik secara fisik maupun spiritual terhadap keberhasilan aktivitas kerja dari yang dipimpin, sehingga menjadi pemimpin itu tidak mudah dan tidak akan setiap orang mempunyai kesamaan di dalam menjalankan kepemimpinannya. Menurut Wahjosumidjo (2005: 17) kepemimpinan di terjemahkan kedalam istilah sifatsifat, perilaku pribadi, pengaruh terhadap orang lain, pola- pola, interaksi, hubungan kerja sama antarperan, kedudukan dari satu jabatan administratif, dan persuasif, dan persepsi dari lain- lain tentang legitimasi pengaruh. Miftah Thoha (2010: 9) kepemimpinan adalah kegiatan untuk memengaruhi perilaku orang lain, atau seni memengaruhi perilaku manusia baik perorangan maupun kelompok.

Kepemimpinan merupakan salah satu faktor yang sangat penting dalam suatu organisai karena sebagian besar keberhasilan dan kegagalan suatu organisasi ditentukan oleh kepemimpinan dalam organisasi tersebut. Menurut C. Turney (1992) dalam Martinis Yamin dan Maisah (2010: 74) mandefinisikan kepemimpinan sebagai suatu group proses yang dilakukan oleh seseorang dalam mengelola dan menginspirasikan sejumlah pekerjaan untuk mencapai tujuan organisasi melalui aplikasi teknik- teknik manajemen. George R. Terry (Miftah Thoha, 2010: 5) mengartikan bahwa Kepemimpinan adalah aktivitas untuk mempengaruhi orang-orang supaya diarahkan mencapai tujuan organisasi. Kepemimpinan meliputi proses mempengaruhi dalam menentukan tujuan organisasi, memotivasi perilaku pengikut untuk mencapai tujuan, mempengaruhi untuk memperbaiki kelompok dan budayanya.

Dale Timple (2000: 58) mengartikan Kepemimpinan adalah:

Proses pengaruh sosial di dalam mana manajer mencari keikutsertaan sukarela dari bawahan dalam usaha mencapai tujuan organisasi. Dengan kepemimpinan yang dilakukan seorang pemimpin juga menggambarkan arah dan tujuan yang akan dicapai dari sebuah organisasi. Sehingga dapat dikatakan kepemimpinan sangat berpengaruh bagi nama besar organisasi.

Menurut Sudarwan Danim (2004: 56) kepemimpinan adalah:

Setiap perbuatan yang dilakukan oleh individu atau kelompok untuk mengkoordinasi dan memberi arah kepada individu atau kelompok yang tergabung di dalam wadah tertentu untuk mencapai tujuan yang telah ditetapkan sebelumnya.

Martinis Yamin dan Maisah (2010: 74) kepemimpinan adalah:
Suatu proses mempengaruhi yang dilakukan oleh seseorang dalam mengelola anggota kelompoknya untuk mencapai tujuan organisasi. Kepemimpinan merupakan bentuk strategi atau teori memimpin yang tentunya dilakukan oleh orang yang biasa kita sebut sebagai pemimpin.

Pemimpin adalah seseorang dengan wewenang kepemimpinannya mengarahkan bawahannya untuk mengerjakan sebagian dari pekerjaannya dalam mencapai tujuan. Pemimpin adalah mereka yang menggunakan wewenang formal untuk mengorganisasikan, mengarahkan, mengontrol para bawahan yang bertanggung jawab, supaya semua bagian pekerjaan dikoordinasi demi mencapai tujuan perusahaan. Pemimpin pertama-tama harus seorang yang mampu menumbuhkan dan mengembangkan segala yang terbaik dalam diri para bawahannya. Secara sederhana pemimpin yang baik adalah seorang yang membantu mengembangkan orang lain, sehingga akhirnya mereka tidak lagi memerlukan pemimpinnya itu.

Menurut Kartini Kartono (2003: 48) mengemukakan kepemimpinan sebagai berikut:

Kepemimpinan itu sifatnya spesifik, khas, diperlukan bagi situasi khusus. Sebab dalam satu kelompok yang melakukan aktivitasaktivitas tertentu, dan punya tujuan serta peralatan khusus, pemimpin kelompok dengan ciri- ciri karakteristiknya itu merupakan fungsi dari situasi khusus tadi. Jelasnya sifat-sifat utama dari pemimpin dan kepemimpinannya harus sesuai dan bisa diterima oleh kelompoknya, juga bersangkutan, serta cocok-pas dengan situasi dan zamannya.

Menurut Gitosudarmo dan Sudita, (1997 : 127) menyatakan bahwa:

"Kepemimpinan merupakan faktor yang sangat penting dalam mempengaruhi prestasi organisasi karena kepemimpinan merupakan aktivitas yang utama dengan mana tujuan organisasi dapat dicapai. Pada umumnya kepemimpinan didefinisikan sebagai suatu proses mempengaruhi aktivitas seseorang atau sekelompok orang untuk mencapai tujuan dalam situasi tertentu.

\section{Teori Kinerja \\ Pengertian Kinerja}

Menurut Prawirosentono (1999: 20) kinerja (performance) adalah :

"Hasil kerja yang dicapai oleh seseorang atau sekelompok orang dalam suatu organisasi, sesuai dengan wewenang dan tanggung jawab masingmasing, dalam rangka upaya untuk mencapai tujuan 
organisasi bersangkutan secara legal, tidak melanggar hukum dan sesuai dengan moral maupun etika"

Indikator-indikator kinerja dalam penelitian ini mengacu pada Prawirosentono (1999 : 27) yaitu :

a. Jumlah pekerjaan

Dapat menyelesaikan sejumlah pekerjaan yang menjadi tanggung jawabnya.

b. Kualitas pekerjaan

Dapat menyelesaikan pekerjaan dengan teliti dan tepat sesuai dengan yang diharapkan

c. Pengetahuan atas tugas

Memiliki pengetahuan yang cukup tentang tugas/ kewajibannya dan melakukannya sehingga mendekati standar perusahaan.

d. Kerja sama

Memiliki kemampuan bekerja sama dengan orang lain dan sikap yang konstruktif dalam tim.

e. Sikap

Memiliki sikap kerja yang menyenangkan dan berusaha konsentrasi pada tugas

f. Tanggung Jawab

Memiliki tanggung jawab dalam melaksanakan tugas/pekerjaan.

g. Inisiatif

Memiliki inisiatif dalam menjalankan tugas/ pekerjaan yang relative baru bagi karyawan.

h. Kreativitas

Memiliki kreativitas untuk menyelesaikan pekerjaan untuk mencapai hasil yang lebih baik.

i. Ketrampilan teknis

Memiliki ketrampilan teknis untuk menyelesaikan pekerjaan

j. Kepemimpinan

Memiliki kemampuan untuk mengarahkan dan membimbing karyawan/pegawai lain untuk mencapai efisiensi dan efektivitas.

k. Pengambilan keputusan

Memiliki kemampuan untuk mengambil keputusan atau menyelesaikan masalah.

1. Administrasi

Memiliki kemampuan menyelesaikan tugastugas administratif.

\section{Kerangka Pemikiran}

Dalam suatu lembaga/organisasi, sumber daya manusia dalam hal ini adalah para pegawai/karyawan yang bekerja harus memiliki motivasi yang tinggi. Pegawai dapat mengaktulisasikan diri sesuai dengan kemampuan yang dimilikinya untuk lebih berperan dalam lembaga/ instansi. Mereka memerlukan kondisi yang mendukung baik dari dalam diri pegawai, berupa motivasi agar dapat bekerja dengan baik untuk memenuhi kebutuhannya, baik kebutuhan akan tercukupinya sandang, pangan, papan, kebutuhan akan rasa aman, serta pengakuan akan keberadaannya dalam bekerja.

Kerangka Pemikiran

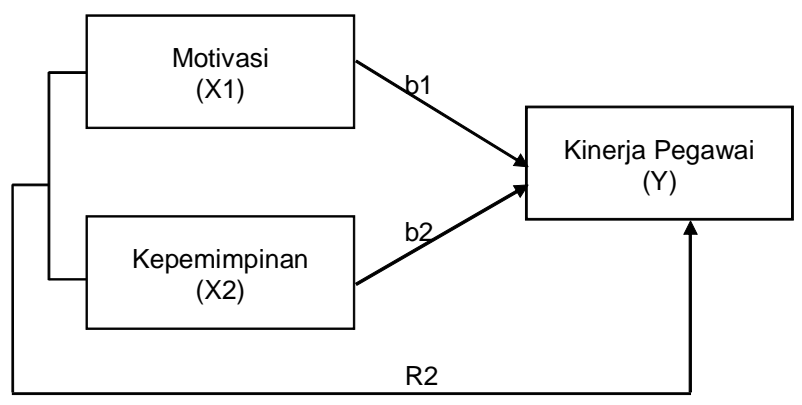

Sumber : Brahmasari dan Suprayitno (2008)

\section{METODOLOGI PENELITIAN}

1. Uji Validitas dan Reliabilitas

\section{a. Uji Validitas}

Uji kualitas terhadap instrumen yang dipakai untuk mengukur variabel penelitian perlu dilakukan sebelum melakukan analisis terhadap pokok masalah.

Validitas adalah suatu ukuran yang menunjukkan tingkat keandalan atau kesahihan suatu alat ukur (Riduwan, 2005: 109). Untuk menguji validitas alat ukur, dengan menggunakan rumus Pearson Product-Moment yang terdapat dalam pengolah data SPSS. Jika instrumen itu valid, maka kriteria yang digunakan atau batas minimum suatu instrumen/angket atau bahan tes dinyatakan valid atau dianggap memenuhi syarat, jika harga koefisien $r$ hitung e+ 0,300 (Sudarmanto, 2005: 88). Adapun rumus korelasi product moment menurut sugiyono (2010:182) adalah sebagai berikut :

$$
r_{x y}=\frac{n \sum x y-\left(\sum x\right)\left(\sum y\right)}{\left.\sqrt{\left.n \sum x^{2}-\left(\sum x\right)^{2}\right]} n \sum y^{2}-\left(\sum y\right)^{2}\right]}
$$

Dimana :

$r_{x y}=$ Koefisien Korelasi antara X dan Y $+\mathrm{xy}=$ Jumlah perkalian antara $\mathrm{X}$ dan $\mathrm{Y}$

$+\mathrm{x}^{2}=$ Jumlah kuadrat $\mathrm{X}$

$+\mathrm{y}^{2}=$ Jumlah kuadrat $\mathrm{Y}$

$\mathrm{N}$ = Jumlah sampel

Jika instrumen itu valid, maka kriteria yang digunakan atau batas minimum suatu instrumen/angket atau bahan tes dinyatakan valid atau dianggap memenuhi 
syarat, jika harga koefisien $r$ hitung e+ 0,300 (Sudarmanto, 2005: 88)

\section{b. Uji Reliabilitas}

Jika alat ukur telah dinyatakan valid, selanjutnya reliabilitas alat ukur tersebut diuji. Reliabilitas menunjukan pada suatu pengertian bahwa suatu instrumen cukup dapat dipercaya untuk digunakan sebagai alat pengumpul data yang tidak bersifat tendensius atau mengarahkan responden untuk memilih jawaban-jawaban tertentu(Sudarmanto, 2005: 89).

Menurut Malhotra (1999: 282), jika koefisien alpha $>0.600$ mengindikasikan konsistensi internal reliabilitas alat ukur yang baik. Konsistensi internal reliabilitas adalah sebuah pendekatan untuk menilai konsistensi internal kumpulan butir ketika beberapa butir dijumlahkan sehingga menghasilkan total nilai (skor) untuk pengukuran (Malhotra, 1999: 282). Untuk mencari reliabilitas instrumen yang skornya bentuk skala 1-5 menggunakan teknik dari Cronbach dalam penelitian ini menggunakan alat bantu pengolah data SPSS

Adapun rumus Alpha menurut Sugiyono (2010:122) untuk mencri nilai reliabilitas sebagai berikut :

$$
\alpha=\left(\frac{K}{K-1}\right)\left(\frac{s_{r}^{2}-\Sigma s_{i}^{2}}{s_{x}^{2}}\right)
$$

Suatu kuesioner dinyatakan realiabel apabila nilai $\mathrm{r}_{\text {hitung }}$ lebih besar daripada nilai $\mathrm{r}_{\text {tabel }}$ dengan taraf signifikasi $5 \%$

\section{Uji Asumsi Klasik}

\section{a. Uji Normalitas}

Salah satu uji persyaratan yang harus dipenuhi dalam penggunaan analisis parametrik yaitu uji normalitas data populasi (Sudarmanto, 200: 105; Riduwan, 2006: 179; dan Umar, 2003:144). Pengujian normalitas distribusi data populasi dilakukan dengan menggunakan statistik Kolmogorov-Smirnov. Alat uji ini biasa disebut dengan uji K-S yang tersedia dalam program SPSS dengan menggunakan fungsi Explore. Uji normalitas sampel baik yang menggunakan rumus KolmogorovSmirnov maupun Shapiro-Wilk menghasilkan besaran statistik dan taraf kepercayaan (Significance Level), jika ditemukan besaran 0.000 atau jauh lebih kecil dari taraf kepercayaan yang ditentukan, misalnya 0.05 , maka besaran ini menunjukkan bahwa data sampel berdistribusi normal (Amir, 2006: 22).

\section{b. Uji Linieritas}

Uji linieritas garis regresi ini digunakan untuk mengambil keputusan dalam memilih model regresi yang akan digunakan. Banyak model regresi yang dapat dipilih, antara lain model linier, model kuadratik, model kubik, dan lain-lain. Jika yang akan dipilh adalah model regresi linier, maka lebih dahulu perlu dilakukan uji linieritas garis regresinya. Uji asumsi linieritas garis regresi ini berkaitan dengan suatu pembuktian apakah model garis linier yang ditetapkan benar-benar sesuai dengan keadaannya ataukah tidak (Sudarmanto, 2005: 125).

Sebagaimana pengujian-pengujian sebelumnya, untuk melakukan uji linieritas garis regresi juga diperlukan hipotesis. Hipotesis yang digunakan untuk menguji linieritas garis regresi tersebut dapat dinyatakan sebagai berikut:

Ho : Model regresi berbentuk linier $\mathrm{Ha}$ : Model regresi berbentuk non-linier Untuk menyatakan apakah garis regresi tersebut linier atau tidak linier atau menerima atau menolak Ho, menurut Sudarmanto (2005: 135), ada dua alternative ukuran yang dapat digunakan. Kedua ukuran tersebut dapat dijelaskan sebagai berikut:

1. Menggunakan harga koefisien signifikansi. Apabila nilai signifikansi yang digunakan untuk menolak atau menerima Ho, maka nilai koefisien signifikansi tersebut harus dibandingkan dengan tingkat alpha yang dipilih oleh peneliti (5\% atau $1 \%)$. Simpulan yang harus diambil, yaitu Ho akan diterima jika nilai signifikansi dari Deviation from Linearity > dari alpha yang ditetapkan (misal, 5\%) dan sebaliknya, Ho akan ditolak jika mempunyai nilai yang lainnya. Deviation from Linearity ini diperoleh dari Tabel 
ANOVA dengan menggunakan program SPSS.

2. Menggunakan harga koefisien F. Yang dimaksud dengan koefisien $\mathrm{F}$ dalam analisis ini adalah harga koefisien F pada baris Deviation from Linearity atau harga $\mathrm{F}$ tuna cocok (Sudjana, 1983, dalam Sudarmanto, 2005: 135) yang tercantum dalam ANOVA Table dari output yang dihasilkan oleh program SPSS. Apabila menggunakan koefisien $\mathrm{F}$ DFL (Deviation from Linearity) atau $F$ tuna cocok, maka harus dibandingkan dengan harga koefisien $\mathrm{F}$ tabel untuk dk pembilang dan $\mathrm{dk}$ penyebut bersesuaian dengan alpha yang telah ditetapkan sebelumnya. Kriteria yang digunakan, yaitu terima Ho, jika Koefisien F hitung d+ F tabel dan tolak Ho, jika F hitung memiliki harga lainnya. Melalui bentuk chart yang ditampilkan juga dapat diterjemahkan untuk melihat normalitas sampel, linieritas, keterhubungan dan kesamaan variansi; suatu persyaratan awal yang harus dipenuhi untuk penggunaan analisis regresi (Amir: 2006: 157). Untuk mengetahui persyaratan linieritas dan kesamaan variansi, dapat membuat plot antara nilai residu (ZRESID) dengan nilai prediksi (ZPRED). Hubungan regresi berbentuk linier dan variansi dapat ditetapkan homogen bila nilai residu dan nilai prediksi tidak ditemukan adanya hubungan. Pada diagram pencar, keterhubungan antara dua garis variabel ditandai dengan adanya garis lurus yang beraturan (Amir, 2006: 157).

\section{c. Uji Multikolinieritas}

Asumsi tidak adanya hubungan yang linier (multikolinieritas) ini hanya berlaku untuk analisis regresi yang modelnya mempunyai fungsi linier ganda (Umar, 2003: 186; Sudarmanto, 2005: 136; Amir, 2006: 174; dan Malhotra,1999: 548). Uji asumsi tentang multikolinieritas ini dimaksudkan untuk membuktikan atau menguji ada tidaknya hubungan yang linier antara variabel bebas (independen) satu dengan variabel bebas (independen) yang lainnya (Sudarmanto, 2005: 136). Ada beberapa cara yang dapat dilakukan untuk mendeteksi adanya multikolinieritas, yaitu:

1. Melihat besaran proporsi variabilitas pada sebuah variabel yang tidak dijelaskan oleh variabel lain $(1-\mathrm{R} 2)$ yang disebut Tolerance. Nilai Tolerance yang sangat kecil atau yang mendekati nilai 0.01 , memberikan makna adanya multikolinieritas atau interkorelasi antar variabel independen. Bila mendekati 0.99, maka tidak ditemukan adanya multikolinieritas. Adanya multikolinieritas akan mengganggu perumusan koefisien regresi, khususnya bila R2 besar, dan bila koefisien regresi pada masing-masing variabel tidak signifikan.

2. Melihat nilai Variance Inflaction Factor (VIF) untuk masing-masing variabel pada setiap model regresi yang bernilai rendah. Indikasi adanya interkorelasi antar variabel independen bila nilai VIP lebih dari 10 (Amir, 2006: 174-175).

\section{d. Uji Autokorelasi}

Auto korelasi merupakan korelasi antar anggotota seri observasi yang disusun menurut urutan waktu seperti data time series atau urutan tempat/ruang data, atau korelasi yang timbul pada dirinya sendiri. Berdasarkan konsep tersebut, maka uji asumsi autokorelasi sangat penting untuk dilakukan tidak hanya pada data yang bersifat time series saja, akan tetapi semua data (variabel independen) yang diperoleh perlu diuji terlebih dahulu autokorelasinya apabila akan dianalisis dengan regresi linier ganda (Sudarmanto, 2005: 142).

Ada tidaknya korelasi dideteksi dengan menggunakan uji Durbin-Watson (Sudarmanto, 2005: 142; Umar, 2003: 189). Ukuran yang digunakan untuk menyatakan ada tidaknya autokorelasi yaitu apabila nilai statistik Durbin-Watson mendekati 2, maka data tidak memiliki autokorelasi (Sudarmanto, 2005: 143) 


\section{Analisis Regresi Linier Berganda}

Tujuan analisa analisis ini adalah untuk mengetahui pengaruh atau hubungan antara variabel bebas dengan variabel terikat baik secara parsial maupun simultan. Analisa data penelitian ini menggunakan analisa Regresi Linier Berganda, yang berfungsi untuk mengetahui pengaruh secara bersama-sama (simultan) maupun sendiri-sendiri (parsial) antara Variabel bebas (X) dengan variabel terikat (Y). Adapun rumus persamaan Regresi Linear Berganda adalah sebagai berikut:

$\mathbf{Y}=\mathbf{a}+\mathbf{b}_{1} \mathbf{x}_{1}+\mathbf{b}_{2} \mathbf{x}_{2}+\mathbf{E}$

Dimana:

$\mathrm{Y}=$ Subyek/nilai dalam variabel terikat yang diprediksikan

$\mathrm{a}=$ Harga $\mathrm{Y}$ apabila $\mathrm{x}=0$ (bilangan konstanta)

$\mathrm{b}=$ Angka arah atau koefisien regresi

$\mathrm{X}_{1}=$ Variabel bebas 1 (Motivasi)

$\mathrm{X}_{2}=$ Variabel bebas 2 (Kepemimpinan)

$b_{1} \cdot b_{2}=$ Koefisien regresi

\section{Uji Hipotesi}

\section{a. Uji $\mathbf{t}$}

Dalam penelitian ini dilakukan uji $t$ yang fungsinya adalah untuk mengetahui pengaruh secara parsial antara variabel bebas (X) dengan variabel terikat (Y). Uji $\mathrm{t}$ dapat dilakukan dengan rumus menurut Sugiono (2008:72) sebagai berikut :

Rumus Hitung

$$
t_{\text {hit }}=\frac{r \sqrt{(n-2)}}{\sqrt{1-r^{2}}}
$$

Keterangan :

$\mathrm{r} \quad=$ Koefisien korelasi

$\mathrm{n}=$ Jumlah Sampel

n-2 = Derajat kebebasan

Setelah dilakukan analisis data maka langkah selanjutnya adalah membandingkan nilai signifikansinya dengan taraf signifikansi 0,05. dari keterangan tersebut dapat ditarik kesimpulan apakah hipotesis nol (Ho) atau hipotesis alternatif (Ha) tersebut ditolak atau diterima. Kriteria untuk penerimaan dan penolakan suatu hipotesis adalah:

1. Nilai thitung $<\mathrm{t}$ tabel, maka hipotesis nol (Ho) diterima dan hipotesis alternatif (Ha) ditolak
2. Nilai t hitung $>\mathrm{t}$ tabel, maka hipotesis nol (Ho) ditolak dan hipotesis alternatif (Ha) diterima.

Atau dengan melihat signifikansi t, yaitu:

1. Signifikansit d $+0,05$, maka hipotesis nol (Ho) ditolak dan hipotesis alternatif (Ha) diterima.

2. Signifikansi $t>0,05$, maka hipotesis nol (Ho) diterima dan hipotesis alternatif (Ha) ditolak.

\section{b. Uji F}

Sedangkan uji $F$ dilakukan untuk mengetahui pengaruh secara bersamasama atau simultan antara variabel bebas (X) dengan variabel terikat (Y). Uji F dapat dilakukan dengan rumus sebagai Berikut :

$$
\mathrm{F}=\frac{\mathrm{R}^{2} / \mathrm{k}}{\left(1-R^{2}\right) /(\mathrm{n}-\mathrm{k}-1)}
$$

Dimana:

$\mathrm{R}=$ Koefisien korelasi linier berganda

$\mathrm{n}=$ Banyaknya data

$\mathrm{k}=$ Banyaknya variabel bebas

Setelah dilakukan analisis data dan diketahui hasil perhitungannya, maka langkah selanjutnya adalah membandingkan nilai signifikansi dengan taraf signifikansi 0,05. dari keterangan tersebut dapat ditarik kesimpulan apakah hipotesis nol (Ho) atau hipotesis alternatif (Ha) tersebut ditolak atau diterima.

Kriteria untuk penerimaan dan penolakan suatu hipotesis adalah:

1. Nilai F hitung $<$ F tabel, maka hipotesis nol (Ho) diterima dan hipotesis alternatif (Ha) ditolak.

2. Nilai F hitung $>$ F tabel, maka hipotesis nol (Ho) ditolak dan hipotesis alternatif (Ha) diterima.

Atau dengan melihat signifikansi F, yaitu:

1. Signifikansi F d+ 0,05, maka hipotesis nol (Ho) ditolak dan hipotesi alternatif (Ha) diterima.

2. Signifikansi $F>0,05$, maka hipotesis nol (Ho) diterima dan hipotesis alternatif (Ha) ditolak. 
Dalam penelitian ini juga dihitung SE (sumbangan efektif) yang digunakan untuk menguji variabel bebas mana yang dominan mempengaruhi variabel terikat. Adapun perhitungannya diperoleh dengan cara mengkuadratkan koefisien korelasi parsial. Rumus untuk mencari sumbangan efektif adalah sebagai berikut:

\section{$\mathrm{SE}=\mathbf{r}^{2} \times 100 \%$}

Dimana angka $\mathrm{r}^{*}$ diperoleh dari analisis regresi coefficients correlation partial. Dan untuk mempermudah penelitian ini, data dianalisis menggunakan SPSS For Windows

\section{ANALISA DAN PEMBAHASAN}

\section{Variabel Motivasi (X1)}

Untuk mengetahui hasil uji variabel independen menggunakan program Statistical Package For Social Sciences (SPSS) for Window input data variabel Motivasi (X1) merupakan data ordinal dari sampel yang berjumlah 17 pernyataan sebagai berikut:

Tabel 5.38

Uji Validitas Variabel Motivasi (X1)

\begin{tabular}{|l|c|c|c|c|}
\hline & $\begin{array}{c}\text { Item-Total Statistics } \\
\text { Scale Mean if } \\
\text { Item Deleted }\end{array}$ & $\begin{array}{c}\text { Scale Variance if } \\
\text { Item Deleted }\end{array}$ & $\begin{array}{c}\text { Corrected Item- } \\
\text { Total Correlation }\end{array}$ & $\begin{array}{c}\text { Cronbach's } \\
\text { Alpha if Item } \\
\text { Deleted }\end{array}$ \\
\hline Pernyataan 1 & 45.73 & 23.942 & .349 & .801 \\
Pernyataan 2 & 46.16 & 21.749 & .598 & .782 \\
Pernyataan 3 & 46.37 & 21.752 & .697 & .777 \\
Pernyataan 4 & 46.43 & 21.894 & .608 & .782 \\
Pernyataan 5 & 46.22 & 22.724 & .515 & .790 \\
Pernyataan 6 & 46.05 & 23.046 & .455 & .794 \\
Pernyataan 7 & 46.63 & 20.945 & .574 & .782 \\
Pernyataan 8 & 46.02 & 23.467 & .452 & .795 \\
Pernyataan 9 & 46.08 & 22.848 & .390 & .799 \\
Pernyataan 10 & 46.13 & 21.822 & .527 & .787 \\
Pernyataan 11 & 47.54 & 21.833 & .509 & .788 \\
Pernyataan 12 & 47.73 & 22.684 & .218 & .826 \\
Pernyataan 13 & 47.30 & 23.666 & .181 & .821 \\
\hline
\end{tabular}

Sumber : data diolah SPSS

Hasil pengolahan data tersebut menunjukkan bahwa dari ke tiga belas butir pernyataan yang terdapat pada variabel motivasi yang memiliki koefisien korelasi > 0.300 sebanyak 11 butir, yaitu P1, P2, P3, P4, P5, P6, P7, P8, P9, P10 dan P11 sehingga dapat dinyatakan bahwa kesebelas butir pernyataan tersebut untuk mengukur variabel motivasi sudah valid. Dua butir lainnya, yaitu P12,P13, tidak valid karena nilai koefisien korelasi $<0.300$.

Nilai korelasi alpha sebesar 0.807 menunjukan bahwa butir pernyataan yang terdapat pada variabel motivasi sudah memiliki nilai reliabilitas yang disarankan, yaitu > 0.600 (Malhotra, 1999: 281; dan Hair et al. 1998, dalam Yuliati, 2003: 84). Artinya instrumen penelitian berupa butir pernyataan yang ada pada variabel motivasi sudah mempunyai kehandalan / konsistensi yang dapat dipertanggungjawabkan.

\section{Variabel Kepemimpinan (X2)}

Tabel 5.39

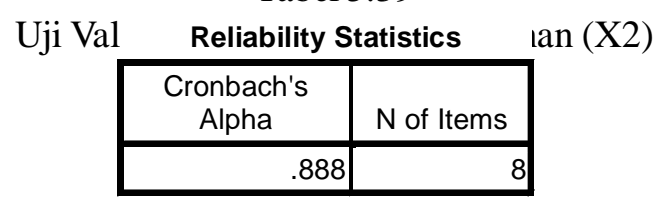

Item-Total Statistics

\begin{tabular}{|l|r|r|r|r|}
\hline & $\begin{array}{c}\text { Item-Total Statistics } \\
\text { Scale Mean if } \\
\text { Item Deleted }\end{array}$ & $\begin{array}{c}\text { Scale Variance if } \\
\text { Item Deleted }\end{array}$ & $\begin{array}{c}\text { Corrected Item- } \\
\text { Total Correlation }\end{array}$ & $\begin{array}{c}\text { Cronbach's } \\
\text { Alpha if Item } \\
\text { Deleted }\end{array}$ \\
\hline Pernyataan 1 & 26.30 & 15.311 & .841 & .855 \\
Pernyataan 2 & 26.49 & 16.189 & .648 & .876 \\
Pernyataan 3 & 26.32 & 16.123 & .811 & .860 \\
Pernyataan 4 & 26.29 & 18.562 & .570 & .884 \\
Pernyataan 5 & 26.49 & 16.222 & .754 & .865 \\
Pernyataan 6 & 26.86 & 15.382 & .674 & .875 \\
Pernyataan 7 & 26.76 & 17.507 & .524 & .887 \\
Pernyataan 8 & 26.60 & 17.921 & .518 & .887 \\
\hline
\end{tabular}

Sumber : data diolah SPSS

Hasil pengolahan data tersebut menunjukkan bahwa dari ke delapan butir pernyataan yang terdapat pada variabel Kepemimpinan (X2). Dari ke delapan butir pernyataan tersebut memiliki koefisien korelasi $>0.300$ sehingga dapat dinyatakan bahwa kedelapan butir pernyataan tersebut untuk mengukur variabel Kepemimpinan sudah valid.

Nilai korelasi alpha sebesar 0.888 menunjukan bahwa butir pernyataan yang terdapat pada variabel Kepemimpinan sudah memiliki nilai reliabilitas yang disarankan, yaitu > 0.600 (Malhotra, 1999: 281; dan Hair et al. 1998, dalam Yuliati, 2003: 84). Artinya instrumen penelitian berupa butir pernyataan yang ada pada variabel Kepemimpinan sudah mempunyai kehandalan / konsistensi yang dapat dipertanggungjawabkan,

\section{Variabel Kinerja (Y)}

Tabel 5.40

Uji Validitas Variabel Kinerja (Y)

Reliability Statistics

\begin{tabular}{|r|r|}
\hline $\begin{array}{c}\text { Cronbach's } \\
\text { Alpha }\end{array}$ & N of Items \\
\hline .711 & 13 \\
\hline
\end{tabular}




\begin{tabular}{|l|r|r|r|r|}
\hline & $\begin{array}{c}|c| \\
\text { Item-Total Statistics }\end{array}$ \\
& $\begin{array}{c}\text { Scale Mean if } \\
\text { Item Deleted }\end{array}$ & $\begin{array}{c}\text { Scale Variance if } \\
\text { Item Deleted }\end{array}$ & $\begin{array}{c}\text { Corrected Item- } \\
\text { Total Correlation }\end{array}$ & $\begin{array}{c}\text { Cronbach's } \\
\text { Alpha if Item } \\
\text { Deleted }\end{array}$ \\
\hline Pernyataan 1 & 45.57 & 12.507 & .637 & .663 \\
Pernyataan 2 & 45.54 & 12.930 & .477 & .679 \\
Pernyataan 3 & 45.54 & 13.317 & .320 & .696 \\
Pernyataan 4 & 45.38 & 13.724 & .250 & .704 \\
Pernyataan 5 & 45.73 & 13.910 & .185 & .712 \\
Pernyataan 6 & 45.49 & 13.544 & .211 & .711 \\
Pernyataan 7 & 46.21 & 14.005 & .134 & .720 \\
Pernyataan 8 & 46.10 & 12.829 & .333 & .695 \\
Pernyataan 9 & 45.98 & 13.790 & .116 & .729 \\
Pernyataan & 46.00 & 12.161 & .483 & .672 \\
10 & 46.00 & 12.935 & .423 & .684 \\
Pernyataan & 45.98 & 13.113 & .335 & .694 \\
11 & 45.71 & 11.949 & .595 & .658 \\
\hline Pernyataan & & & & \\
12 & & & & \\
Pernyataan & & & & \\
13 & & & & \\
\hline
\end{tabular}

Sumber : data diolah SPSS

Hasil pengolahan data di atas menunjukan bahwa dari ketiga belas butir pernyataan pada kinerja pedawai, ada 5 butir pernyataan yang memiliki nilai koefisien korelasi $<0.300$ yang mengindikasikan ketidakvalidan, yaitu: P4, P5, P6, P7 dan P9.

1. Uji Normalitas

Untuk mengetahui distribusi normal tidaknya data-data variabel independen (X1 dan X2) maupun variabel dependen (Y), maka penulis menggunakan perhitungan Chi kuadrat dengan program computer Statistical Package for Social Sciences (SPSS)

Tabel 5.41

Hasil Uji Normalitas Dengan KolmogorovSmirnov

One-Sample Kolmogorov-Smirnov Test

\begin{tabular}{|ll|r|}
\hline & & $\begin{array}{r}\text { Unstandardiz } \\
\text { ed Residual }\end{array}$ \\
\hline $\mathrm{N}$ & Mean & 63 \\
Normal Parameters & $\mathrm{a}$ & .0000000 \\
& Std. Deviation & 2.72839728 \\
Most Extreme Differences & Absolute & .150 \\
& Positive & .150 \\
& Negative & -.102 \\
Kolmogorov-Smirnov Z & & 1.189 \\
Asymp. Sig. (2-tailed) & & .118 \\
\hline
\end{tabular}

a. Test distribution is Normal.

Sumber : data diolah SPSS

Berdasarkan output pada tabel 5.41 diatas, diketahui bahwa nilai signifikasi sebesar 0.118 lebih besar dari 0.05 sehingga dapat disimpulkan bahwa data berdistribusi normal
2. Uji Linieritas

Uji linearitas bertujuan untuk mengetahui apakah dua variabel mempunyai hubungan yang linear atau tidak secara signifikan. Uji ini biasanya digunakan sebagai prasyarat dalam analisis korelasi atau regresi linear.Pengujian pada SPSS dengan menggunakan Test for Linearity dengan pada taraf signifikansi 0,05 . Dua variabel dikatakan mempunyai hubungan yang linear bila signifikansi (Linearity) kurang dari 0,05 .

Tabel 5.42

Hasil Uii Linieritas Motivasi dan Kineria ANOVA Table

\begin{tabular}{|c|c|c|c|c|c|c|c|}
\hline & & & $\begin{array}{c}\text { Sum of } \\
\text { Squares }\end{array}$ & df & $\begin{array}{l}\text { Mean } \\
\text { Square }\end{array}$ & $\mathrm{F}$ & Sig. \\
\hline \multirow{5}{*}{$\begin{array}{l}\text { KINERJA * } \\
\text { MOTIVASI }\end{array}$} & Between & (Combined) & 588.128 & 15 & 39.209 & 5.342 & .000 \\
\hline & & Linearity & 203.234 & 1 & 203.234 & 27.691 & .000 \\
\hline & & $\begin{array}{l}\text { Deviation from } \\
\text { Linearity }\end{array}$ & 384.894 & 14 & 27.492 & 3.746 & .000 \\
\hline & \multicolumn{2}{|c|}{ Within Groups } & 344.951 & 47 & 7.339 & & \\
\hline & \multicolumn{2}{|l|}{ Total } & 933.079 & 62 & & & \\
\hline
\end{tabular}

Sumber : data diolah SPSS

Dari hasil uji linieritas diatas, diperoleh nilai signifikasi 0.000 lebih kecil dari 0.05 yang artinya bahwa tidak terdapat hubungan yang linier secara signifikan antara Motivasi dan Kinerja Tabel 5.43

Hasil Uji Linieritas Kepemimpinan dan Kinerja

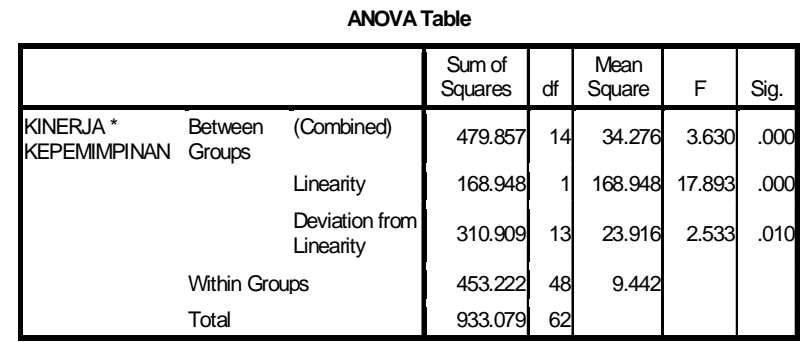

Sumber : data diolah SPSS

Dari hasil uji linieritas diatas, diperoleh nilai signifikasi 0.010 lebih besar dari 0.05 yang artinya bahwa terdapat hubungan yang linier secara signifikan antara Kepemimpinan dan Kinerja 
3. Uji Multikolinieritas

Uji multikolinearitas digunakan untuk mengetahui ada atau tidaknya penyimpangan asumsi klasik multikolinearitas yaitu adanya hubungan linear antar variabel independen dalam model regresi dengan melihat nilai inflation factor (VIF) pada model regresi dan membandingkan nilai koefisien determinasi individual $\left(\mathrm{r}^{2}\right)$ dengan nilai determinasi secara serentak $\left(\mathrm{R}^{2}\right)$. Menurut Santoso (2001), pada umumnya jika VIF lebih besar dari 5, maka variabel tersebut mempunyai persoalan multikolinearitas dengan variabel bebas lainnya.

Tabel 5.44

Hasil Uji Multikolinieritas

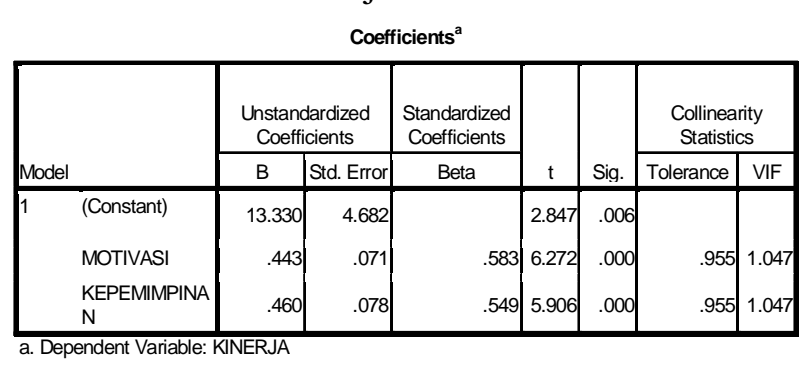

Sumber : data diolah SPSS

Berdasarkan hasil uji multikolinieritas bahwa nilai tolerance lebih besar dari 0.10 , sedangkan nilai VIF lebih kecil dari 10.00, sehingga dapat disimpulkan tidak terjadi multikolinieritas.

Tabel 5.45

Hasil Uji Autokorelasi

\begin{tabular}{|l|c|r|r|r|r|}
\hline Model & $\mathrm{R}$ & $\mathrm{R}$ Square & $\begin{array}{r}\text { Adjusted } \\
\text { R Square }\end{array}$ & $\begin{array}{c}\text { Std. Error of the } \\
\text { Estimate }\end{array}$ & Durbin-Watson \\
\hline 1 & $.711^{\mathrm{a}}$ & .505 & .489 & 2.773 & 1.546 \\
\hline
\end{tabular}
a. Predictors: (Constant), KEPEMIMPINAN, MOTIVASI
b. Dependent Variable: KINERJA

Sumber : data diolah SPSS

Berdasarkan hasil uji autokorelasi pada tabel 5.45 diatas, diketahui nilai DW 1.546 selanjutnya nilai ini akan dibandingkan dengan nilai tabel signifikasi 5\% jumlah sampel $\mathrm{N}=63$ dan jumlah variabel independen $2(\mathrm{~K}=2)=2.63$ maka diperoleh nilai du 1.658. Nilai DW 1.546 lebih besar dari nilai du batas atas yakni 1.658 dan kurang dari (4-du) 4-1.658 = 2.342 maka dapat disimpulkan tidak terdapat autokorelasi

\section{Regresi Linier Berganda}

Tujuan dari analisis regresi linier berganda ini untuk mengetahui arah hubungan antara variabel independen dengan variabel dependen apakah masing-masing variabel independen berhubungan positif atau negatif dan untuk memprediksi nilai dari variabel dependen apabila nilai variabel independen mengalami kenaikan atau penurunan.

Persamaan regresi linear berganda sebagai berikut:

$\mathrm{Y}^{\prime}=\mathrm{a}+\mathrm{b}_{1} \mathrm{X}_{1}+\mathrm{b}_{2} \mathrm{X}_{2}+\ldots .+\mathrm{b}_{\mathrm{n}} \mathrm{X}_{\mathrm{n}}$

Keterangan:

$\mathrm{Y}^{\prime}=$ Variabel dependen (nilai yang diprediksikan)

$\mathrm{X}_{1}$ dan $\mathrm{X}_{2}=$ Variabel independen

$\mathrm{a}=$ Konstanta (nilai $Y^{\prime}$ apabila $\mathrm{X}_{1}, \mathrm{X}_{2} \ldots . . \mathrm{X}_{\mathrm{n}}=0$ )

$\mathrm{b}=$ Koefisien regresi (nilai peningkatan ataupun penurunan)

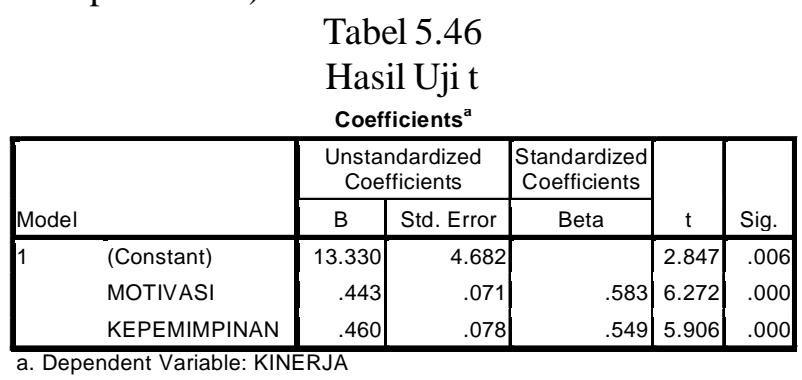

Sumber : data diolah SPSS

\section{Uji Koefisien Regresi Secara Parsial}

a. Pengujian koefisien regresi variabel Motivasi Secara Parsial

Berdasarkan hasil perhitungan pada tabel 5.46 diatas nilai -t hitung > -t tabel $(6,272$ $>2,000)$ maka Ho diterima, artinya secara parsial tidak ada pengaruh signifikan antara Motivasi dengan Kinerja. Jadi dari kasus ini dapat disimpulkan bahwa secara parsial Motivasi tidak berpengaruh terhadap Kinerja pegawai pada Kantor Kecamatan Pusakajaya Kabupaten Subang.

b. Pengujian koefisien regresi variabel Kepemimpinan Secara Parsial

Berdasarkan hasil perhitungan pada tabel 5.46 diatas nilai -t hitung > $\mathrm{t}$ tabel $(5,906$ $<2,000)$ maka Ho ditolak, artinya secara parsial ada pengaruh signifikan antara Kepemimpinan dengan Kinerja. Dari kasus ini dapat disimpulkan bahwa secara parsial Kepemimpinan berpengaruh terhadap Kinerja pegawai pada Kantor Kecamatan Pusakajaya Kabupaten Subang. 


\section{Uji Koefisien Regresi Secara Bersama- sama (Uji F)}

Tabel 5.47

Hasil Uji F

ANOVA $^{\text {D }}$

\begin{tabular}{|c|c|c|c|c|c|c|}
\hline \multicolumn{2}{|c|}{ Model } & $\begin{array}{l}\text { Sum of } \\
\text { Squares }\end{array}$ & df & Mean Square & $\mathrm{F}$ & Sig. \\
\hline \multirow[t]{3}{*}{1} & Regression & 471.542 & 2 & 235.771 & 30.650 & $.000^{\mathrm{a}}$ \\
\hline & Residual & 461.537| & 60 & 7.692 & & \\
\hline & Total & 933.079 & 62 & & & \\
\hline
\end{tabular}

Sumber : data diolah SPSS

Dengan menggunakan tingkat keyakinan $95 \%$, á $=5 \%$, df 1 (jumlah variabel-1) $=2$, dan df 2 (n-k-1) atau 63-2-1 = 60 (n adalah jumlah kasus dan $\mathrm{k}$ adalah jumlah variabel independen), hasil diperoleh untuk $\mathrm{F}$ tabel sebesar 3,15. Karena F hitung $>$ F tabel $(30.650<3,15)$, maka Ho ditolak, artinya ada pengaruh secara signifikan antara Motivasi dan Kepemimpinan secara bersama-sama terhadap terhadap Kinerja. Jadi dari kasus ini dapat disimpulkan bahwa Motivasi dan Kepemimpinan secara bersama-sama berpengaruh terhadap Kinerja pegawai pada Kantor Kecamatan Pusakajaya Kabupaten Subang.

\section{Analisis Determinasi $\left(\mathbf{R}^{2}\right)$}

Tabel 5.48

Hasil Analisis Determinasi

Model Summary

\begin{tabular}{|l|c|r|r|c|}
\hline Model & $\mathrm{R}$ & $\mathrm{R}$ Square & $\begin{array}{c}\text { Adjusted R } \\
\text { Square }\end{array}$ & $\begin{array}{c}\text { Std. Error of the } \\
\text { Estimate }\end{array}$ \\
\hline 1 & $.711^{\mathrm{a}}$ & .505 & .489 & 2.773 \\
\hline
\end{tabular}

a. Predictors: (Constant), KEPEMIMPINAN, MOTIVASI

Sumber : data diolah SPSS

Berdasarkan tabel 5.48 di atas diperoleh angka $\mathrm{R}^{2}$ (R Square) sebesar 0,505 atau (50,5\%). Hal ini menunjukkan bahwa prosentase sumbangan pengaruh variabel independen (Motivasi dan Kepemimpinan) terhadap variabel dependen (Kinerja) sebesar $50.5 \%$. Atau variasi variabel independen yang digunakan dalam model (Motivasi dan Kepemimpinan) mampu menjelaskan sebesar $52 \%$ variasi variabel dependen (Kinerja). Sedangkan sisanya sebesar $49.5 \%$ dipengaruhi atau dijelaskan oleh variabel lain yang tidak dimasukkan dalam model penelitian ini.

\section{KESIMPULAN DAN SARAN KESIMPULAN}

Berdasarkan dari hasil analisis dan pembahasan yang telah penulis bahas pada bab sebelumnya. Maka penulis menarik suatu kesimpulan sebagai berikut :

1. Berdasarkan hasil perhitungan nilai -t hitung > $\mathrm{t}$ tabel $(6,272>2,000)$ maka Ho diterima, artinya secara parsial tidak ada pengaruh signifikan antara Motivasi dengan Kinerja. Jadi dari kasus ini dapat disimpulkan bahwa secara parsial Motivasi tidak berpengaruh terhadap Kinerja pegawai pada Kantor Kecamatan Pusakajaya Kabupaten Subang.

2. Berdasarkan hasil perhitungan nilai -t hitung > -t tabel $(5,906>2,000)$ maka Ho ditolak, artinya secara parsial ada pengaruh signifikan antara Kepemimpinan dengan Kinerja. Dari kasus ini dapat disimpulkan bahwa secara parsial Kepemimpinan berpengaruh terhadap Kinerja pegawai pada Kantor Kecamatan Pusakajaya Kabupaten Subang.

3. Berdasarkan hasil perhitungan Karena $F$ hitung $>\mathrm{F}$ tabel $(30.650<3,15)$, maka Ho ditolak, artinya ada pengaruh secara signifikan antara Motivasi dan Kepemimpinan secara bersama-sama terhadap terhadap Kinerja. Jadi dari kasus ini dapat disimpulkan bahwa Motivasi dan Kepemimpinan secara bersama-sama berpengaruh terhadap Kinerja pegawai pada Kantor Kecamatan Pusakajaya Kabupaten Subang.

\section{SARAN-SARAN}

Berdasarkan kesimpulan yang telah di uraikan, maka saran yang dapat diberikan adalah :

1. Pihak Kantor Kecamatan Pusakajaya Kabupaten Subang dapat lebih memfokuskan perhatiannya untuk usaha-usaha peningkatan motivasi kerja karyawan karena motivasi mempunyai andil yang besar terhadap kinerja karyawan. Peningkatan motivasi dapat dilakukan dengan pemenuhan kebutuhan berprestasi, kebutuhan afiliasi dan kebutuhan kekuasaan

2. Kepemimpinan memiliki pengaruh terhadap kinerja pegawai, jadi sebaiknya pimpinan memperhatikan motivasi motivasi yang kurang diperhatikan agar kinerja pegawai lebih ditingkatkan lagi.

3. Peningkatan kinerja ASN tentu tidak lepas dari SDM (Sumber Daya Manusia) ASN itu sendiri. Saat uraian jabatan sudah diuraikan dengan baik, 
kompetensi pegawai harus disesuaikan dengan tanggung jawab yang tertuang di dalam uraian jabatan tersebut. Pemilihan calon ASN saat rekrutmen menjadi krusial untuk mempekerjakan orang-orang yang kompeten. Pemilihan pelatihan yang tepat guna pun menjadi krusial untuk meningkatkan kompetensi pegawai yang bersangkutan.

\section{DAFTAR PUSTAKA}

Amir, 2006 Mengolah dan Membuat Interprestasi Hasil Olahan. SPSS untuk penelitian ilmiah. Jakarta: Penerbit Edsa

Arikunto, Suharsimi 2012. Prosedur Penelitian Suatu Pendekatan Praktis. Edisi Revisi VI. Jakarta: PT. Rineka Cipta.

Arikunto, S. 2013.Prosedur Penelitian Suatu Pendekatan Praktik. Edisi Revisi. Jakarta: PT. Rineka Cipta. Althof, dkk. 2006

C. Turney 1992 Conceptualising the management process) New Jersey: Prentice. Hall Inc. Cascio

Cahyono, Budhi dan Suharto, 2005, Pengaruh Budaya Organisasi, Kepemimpinan dan Motivasi Kerja Terhadap Kinerja Sumber Daya Manusia Di Sekretariat DPRD Propinsi Jawa Tengah, Jurnal, JRBI Vol.1, Yogyakarta

Dale Timple 2000 Memimpin Manusia, Seri Manajemen Sumber Daya Manusia,. Jakarta, Gramedia

Elida Prayitno, 1989 Motivasi Dalam Belajar. Jakarta : Depdikbud

Gitosudarmo dan Sudita, 1997 Perilaku Keorganisasian. BPFE. Yogyakarta. , Indriyo, dan Sudita, I Nyoman, 1997, Perilaku Organisasi, Edisi Pertama, BPFE, Yogyakarta.

Hadari Nawawi 2005 Metode Penelitian Bidang Sosial. Yogyakarta: Gadjah Mada. University Press

Handoko 1992 Manajemen Personalia Dan Sumber Daya. Manusia, Edisi kedua Yogyakarta 2001 Manajemen Personalia dan Sumberdaya Manusia,Edisi. Kedua. BPFE, Yogyakarta

Hasibuan 2003 Manajemen Sumber Daya Manusia, Edisi Revisi,. Bumi Aksara, Jakarta

Kartini Kartono 2003 Patologi Sosial 2, Kenakalan Remaja Penerbit: Rajawali

Malhotra 1999 Consumer Behavior and Marketing. Strategy. Fifth Edition. Singapore: Mc Graw Hill.
Mangkunegara 2005 Sumber Daya Manusia perusahaan. Remaja. Rosdakarya

Martin Handoko, 1992 Motivasi Daya Penggerak Tingkah Laku, Jakarta: Rineka Cipta

Martinis Yamin dan Maisah 2010 Standarisasi Kinerja Guru. Jakarta: Persada. Press.

Miftah Thoha 2010 Kepemimpinan dan manajemen masa depan. Bogor: IPB Press

Nawawi, Hadari, 2000, Manajemen Sumber Daya Manusia, UGM, Yogyakarta

Ngalim Purwanto,1998 Psikologi Pendidikan, Bandung: Remaja Rosdakarya

Nursalam 2008 Konsep dan Penerapan Metodologi Penelitian Ilmu Keperawatan, Jakarta

Oemar Hamalik, 2004 Proses Belajar Mengajar, Jakarta Bumi Aksara

Pamudji, S. 1993, Kepemimpinan Pemerintah Indonesia, Bumi Aksara, Bandung.

Prawirosentono, Suyadi, 1999, Kebijakan Kinerja Karyawan, BPFE, Yogyakarta.

Reksohadiprodjo, Sukanto dan Handoko, T. Hani, 2001, Organisasi Perusahaan: Teori Struktur dan Perilaku, Edisi Kedua, BPFE, Yogyakarta.

Riduwan 2007 Metode Penelitian untuk Tesis. Bandung: Alfabeta

2006 Metode dan tekhnik Menyusun Tesis. Bandung : Alfabeta.

Robbins \& Coulter, 2007 Manajemen, Edisi Kedelapan, Penerbit PT. Indeks: Jakarta

Sardiman A.M, 2009 Interaksi dan Motivasi Belajar Mengajar. Jakarta. PT. Rajawali Pers.

Siagian 1995 Manajemen Sumber Daya Manusia, Jakarta, PT. Elek Media Kompetindo.

Sonny Harsono 2004 Pengantar Metode Penelitian. Hukum, PT. Raja Grafindo

Suarli dan Bahtiar, 2010 Manajemen Keperawatan dengan Pendekatan Praktis. Erlangga

Sudarmanto, 2005 . Analisis Regresi Linear Ganda dengan SPSS. Yogyakarta: Graha

Sudarwan Danim 2004 Motivasi Kepemimpinan dan Efektivitas Kelompok. Penerbit Rineka Cipta

Sugiyono 2010 MetodePenelitian Kuantitatif Kualitatif \& RND. Bandung : Alfabeta , 2008, Metode Penelitian Bisnis, CV.Alfabeta, Bandung

Suharsini Arikunto 2005 ManajemenPenelitian. Jakarta: Rineka Cipta.

Umar, 2003 Metodologi Penelitian Untuk Skripsi dan Tesis Bisnis,Jakarta. : PT. Gramedia Pustaka

Wahjosumidjo 2005 Kepemimpinan Kepala Sekolah. Jakarta: Rajawali Grafindo. Persada 